\title{
Batteries in a vehicle - conditions, capabilities and limitations
}

\author{
Piotr Julian Biczel ${ }^{1, *}$ and Maciej Kwiatkowski ${ }^{1,2}$ \\ ${ }^{1}$ Warsaw University of Tehcnology, IETiSIP \\ ${ }^{2}$ Impact Clean Power Technology S.A.
}

\begin{abstract}
Electric buses are now seen as the primary means of public transport in cities. However, their exploitation is associated with a number of limitations. The article presents the problem of battery use in buses. The design differences between the vehicle with the internal combustion engine and the electric motor are discussed. In particular, authors compared the number of passengers that both types of buses can take, as well as the difference in vehicle mass and range, and the reasons for these differences. The types of electrochemical cells that can be used to power vehicles and their basic features are presented. The article focuses on the NMC, LFP, LTO and LIC type cells. Next, the battery pack structure and its components were described. The specific energies of cells and batteries constructed from these cells were compared. Next, the most important features of the vehicle equipped with batteries with various types of cells are discussed. The mass, range, charging time and cycle lifetime of the batteries were compared. The basic dependence was noted: the greater the specific energy, the smaller the number of battery cycles. So if the bus has to take more passengers, it must have light batteries, which should be frequently charged, which requires high cyclic lifetimes.
\end{abstract}

\section{Introduction}

The increasing number of population as well as migration to cities, causes more and more difficulties in moving the population. Individual transport is inefficient and must be replaced by collective transport in the shorter term. In addition to lengthening travel time and cost increasing, environmental impact of transport means is an important factor. At present, mainly contamination with dust, nitrogen oxides and noise is mentioned here. These problems can be largely resolved by introducing common electric transport, including road transport. It can be said that the development of electric transport is not at risk, because electric vehicles are, for the time being, the best remedy for pollution and noise.

It should be expected that also in public transport, electric traction, including road traction, will develop. However, more and more often we will drive without traction network. This is evident from the dynamic development of electric bus constructions and the increasing number of cities interested in introducing electric vehicle fleets [1]. The figure 1 presents the forecast of the bus market development in Europe [2].

Electricity can be easily generated, transferred, regulated, and processed, but cannot be saved for later or transported without connection to the source. Completely different from liquid fuels, both fossil and biofuels. At present, electric energy is exclusively stored only in electrochemical batteries. Unfortunately, they have many drawbacks compared to liquid fuels. Above all, small specific energies and limited cycle lifetime.

*e-mail: biczel@ee.pw.edu.pl

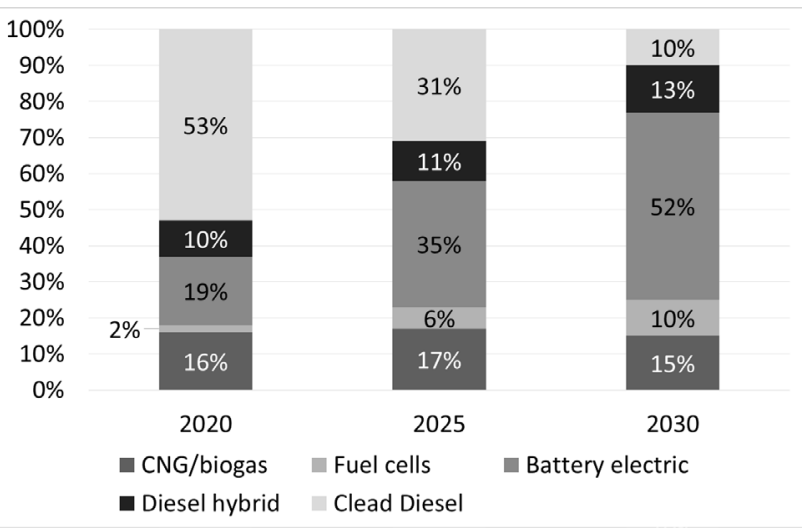

Figure 1. Forecast of buses technology development in Europe [2]

It is also worth mentioning that electric vehicles can be powered by low-emission energy. It is enough to ensure that the power used in them will be produced in zeroemission and renewable sources.

There are therefore many reasons for switching from oil-based transport to electric one. One should wonder how the above-mentioned problems affect the bus's ability and how it can be dealt with.

\section{C rate}

In the further part of the article there will often be a coefficient written as $\frac{1}{x} \mathrm{C}$ or $\mathrm{C} / \mathrm{x}$ used, where $\mathrm{x}$ is the time the battery is discharged and $\mathrm{C}$ its nominal capacity in $[\mathrm{Ah}]$ 
Table 1. Composition of lithium ion cell electrodes of various types

\begin{tabular}{ccc}
\hline Cell type & Cathode & Anode \\
\hline NMC & $\mathrm{LiNi}_{x} \mathrm{Mn}_{\mathrm{y}} \mathrm{Co}_{\mathrm{z}} \mathrm{O}_{2}$ & graphite \\
LFP & $\mathrm{LiFePO}_{4}$ & graphite \\
LTO & $\mathrm{LiCoO}_{2}$ & $\mathrm{Li}_{4} \mathrm{Ti}_{5} \mathrm{O}_{12}$ \\
\hline
\end{tabular}

(charge). We say that the battery is discharged with $\mathrm{C} / \mathrm{x}$ current, so called $\mathrm{x}$-hour discharging current, if a nominal charge of $\mathrm{C}$ is taken from it within $\mathrm{x}$ hours. This coefficient has the dimension in $[\mathrm{A}]$ and is used to compare the discharge currents of different types and capacities.

The form $\frac{1}{x} \mathrm{C}$ is used mainly for discharge currents shorter than one hour and $\mathrm{C} / \mathrm{x}$ for onger one. I.e. 5-hours current, $\mathrm{C} / 5$ or $0,2 \mathrm{C}$, for $20 \mathrm{Ah}$ cell is $4 \mathrm{~A}$ :

$$
C / 5=\frac{20 A h}{5 h}=4 A
$$

and 6-minutes current (1/10 of hour), $\mathrm{C} / 0,1$ or $10 \mathrm{C}$, for the same cell:

$$
10 C=\frac{20 A h}{0.1 h}=200 A
$$

Lithium-ion batteries are mainly intended for short discharges, from 3 hours to several minutes $(C / 3-10 C)$, therefore the form of $\frac{1}{x} \mathrm{C}$ will be used here more often in following sections. [3].

This coefficient is formally defined, for example, in

In practice, the current given in the form $\mathrm{C} / \mathrm{x}$ (coefficient $\mathrm{C} / \mathrm{x}$ ) allows to compare cells of different types and capacities. It makes the charging current independent of the battery capacity.

\section{Recharchable cell for vehicles}

The basic parameters that determine the use of a given cell in a vehicle are: discharge current, specific energy, number of cycles and operating temperature.

Among the many types of lithium-ion cells used in vehicles [4], buses currently use the following three types of lithium-ion cells: NMC, LFP [5], LTO [6] (table 1). In the near future LIC [7] and new NMC battery types - NMC811 [8] will join the group. The cells differ in the structure and chemical composition of electrodes and electrolyte, and hence the capacity, charging and discharging power, environmental conditions of work and - above all - energy density $\left[\mathrm{Wh} / \mathrm{dm}^{3}\right]$ and specific energy $[\mathrm{Wh} / \mathrm{kg}]$.

The LIC cells behave almost like capacitors. And they have similar power parameters and number of cycles. However, they have a very small capacity and specific energy. The bus, supplied with those cell, would have to be loaded every 2-3 stops.

Currently used NCM batteries have an equal amount of nickel, cobalt and manganese, what is marked as NMC111. Soon, cells with a different ratio of these elements will be introduced to the market, the so-called

\begin{tabular}{|c|c|c|c|c|c|}
\hline Cell type & $\begin{array}{l}\text { Disch. } \\
\text { curr. }\end{array}$ & $\begin{array}{l}\text { Char. } \\
\text { curr. }\end{array}$ & $\begin{array}{l}\text { Temp. of } \\
\text { oper. }\end{array}$ & $\begin{array}{l}\text { No. } \\
\text { cycles }\end{array}$ & of \\
\hline NMC & $2 \mathrm{C}$ & $2 \mathrm{C}$ & $\begin{array}{l}-20^{\circ} \mathrm{C}- \\
+60^{\circ} \mathrm{C}\end{array}$ & $\begin{array}{l}300 \\
7000\end{array}$ & - \\
\hline LFP & $4 \mathrm{C}$ & $5 \mathrm{C}$ & $\begin{array}{l}-30^{\circ} \mathrm{C}- \\
+50^{\circ} \mathrm{C}\end{array}$ & $\begin{array}{l}2000 \\
7000\end{array}$ & - \\
\hline LTO & $20 \mathrm{C}$ & $10 \mathrm{C}$ & $\begin{array}{l}-30^{\circ} \mathrm{C}- \\
+40^{\circ} \mathrm{C}\end{array}$ & $\begin{array}{l}\text { approx. } \\
50000\end{array}$ & \\
\hline LIC & $200 \mathrm{C}$ & $200 \mathrm{C}$ & $\begin{array}{l}-30^{\circ} \mathrm{C}- \\
+70^{\circ} \mathrm{C}\end{array}$ & $\begin{array}{l}\text { approx. } \\
500000\end{array}$ & \\
\hline
\end{tabular}

Table 2. Parameters of selected types of lithium-ion cells

NMC811 cells [8]. They are very light and cheap, but they do not have enough cycles. Pending replacement of batteries every $3-4$ years is considered, Total Cost of Ownership would be larger, but the bus would have better performance - range or payload.

Typical parameters of the above mentioned cells are presented in the table 2 . It can be seen that cells with a higher number of cycles can be discharged and charged with higher powers (high C-rate) in relation to capacity than cells with lower number of cycles.

However, the price of a large number of cycles and large currents is low specific energy. This is due to the fact that the cell has a higher C-rate current and number of cycles, the more they behave like capacitors, not electrochemical cells. Capacitors, however, have small specific energies.

Figure 2 presents a comparison of the specific energy and energy densities of the cells in question. Figure 3 presents the change in the energy density of the individual cell types as a function of the number of cycles.

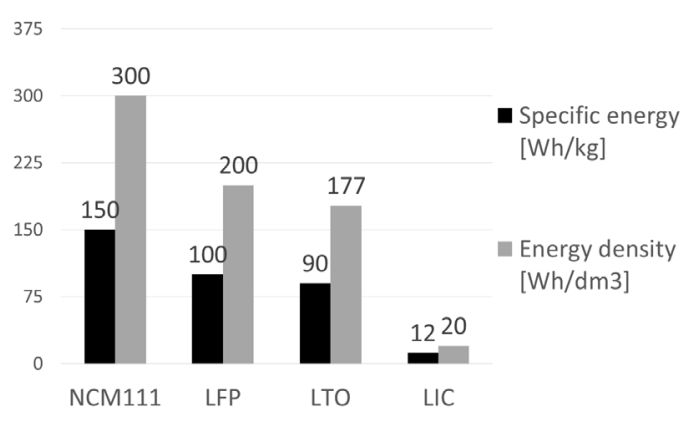

Figure 2. Energy density and specific energy of selected cells

\section{A bus}

A typical urban bus, most frequently used in Europe, is 12 $\mathrm{m}$ long (figure 4) [1]. A bus, produced by one of the leading manufacturers, in the diesel engine version can take 105 people on board. Its gross vehicle mass (GVM) is 18 tons, and its deadweight load is in the order of $10.4-13.2$ 


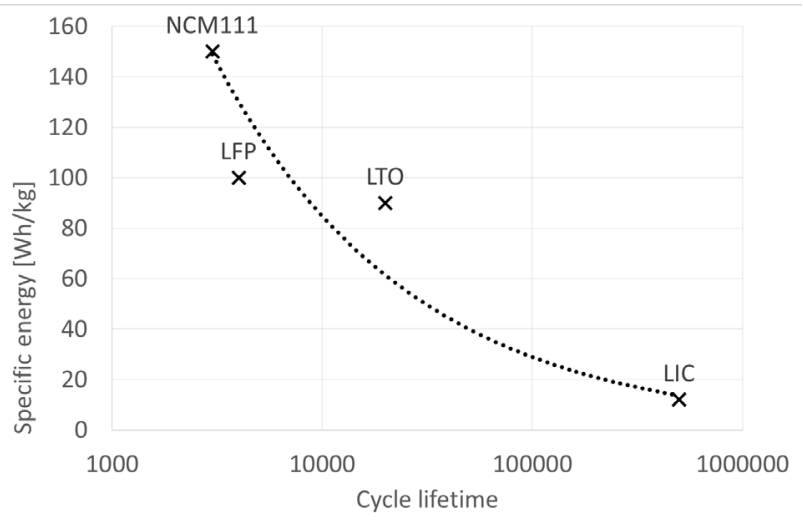

Figure 3. Energy density vs. cycle lifetime of selected cells

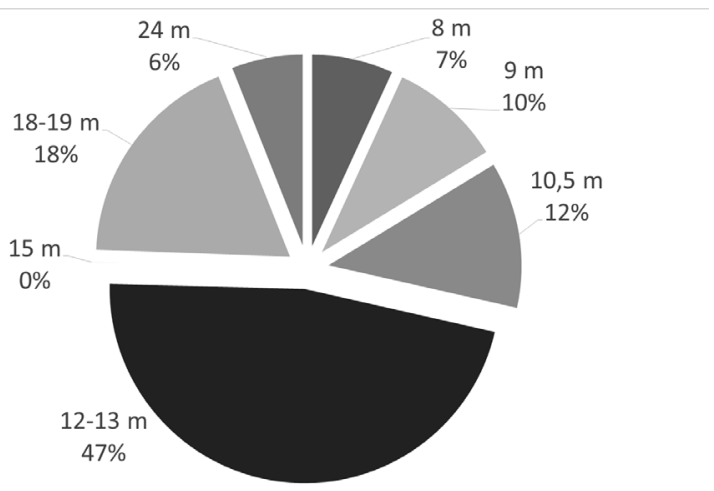

Figure 4. The share of electric buses of different lengths in the European market [1]

tons. It is driven by a $200 \mathrm{~kW}$ engine. An electric bus built on the same chassis and with the same body can take only 83 passengers according to the manufacturer. His GVM is also $18 \mathrm{t}$ and it is driven by a $160 \mathrm{~kW}$ engine.

So, what difference does the number of passengers have if the GVMs are the same and the other parameters are similar?

To answer this question, compare the weight of both vehicles. The difference in the number of passengers taken is 22 people. An average mass of these people is about $1700 \mathrm{~kg}$. Changing the electric bus into an electric one turns the part of the internal combustion drivetrain:

- comustion engine along with the equipment,

- gear box,

- fuel tank

into electric one:

- electric motor,

- drive powerelectronic converter,

- $24 \mathrm{~V}$ auxiliary powerelectronic converter,

- baterries along with the equipment.

The comparison of the mass of these elements is presented in the table 3.
Table 3. Comparison of the mass of the combustion and electric bus components

\begin{tabular}{ll|ll}
\hline \multicolumn{2}{c|}{ Combustion bus } & \multicolumn{2}{c}{ Electric bus } \\
\hline Component & $\begin{array}{l}\text { Mass } \\
{[\mathrm{kg}]}\end{array}$ & Component & $\begin{array}{l}\text { Mass } \\
{[\mathrm{kg}]}\end{array}$ \\
\hline Engine & 500 & Motor & 350 \\
Gear box & 270 & $\begin{array}{l}\text { Drive con- } \\
\text { verter }\end{array}$ & 100 \\
Fuel tank & 350 & $\begin{array}{l}24 \quad \text { V aux. } \\
\text { converter }\end{array}$ & 150 \\
& & Battery & $?$ \\
\hline Total & 1120 & Total & $600+?$ \\
\hline
\end{tabular}

It is easy to notice that the combined mass of the listed components from the combustion engine bus is $1120 \mathrm{~kg}$. Components of the electric bus, in addition to the batteries have a total mass of $600 \mathrm{~kg}$. Thus, these electric vehicle components are $620 \mathrm{~kg}$ lighter. The secret is hidden in the mass of the battery, which must give a mass increase of approx. $1100 \mathrm{~kg}$ - as much as the mass of missing passengers reduced by the mass of electrical components.

How is it constructed and what is the battery of the bus composed of?

\section{Battery in a bus}

The battery in the bus is made of several hundred cells connected in series and in parallel. In addition to the cells, it consists of many other elements. Following can mention here:

- security housing,

- electrical protection,

- contactors,

- BMS battery management system,

- cooling and heating systems,

- wiring.

All this causes that the battery in the bus has the resulting specific energy lower than the cells it is made (figure 5). This difference is particularly high in the case of high C-rate current batteries, which require particularly more intensive cooling than low C-rate current ones.

Batteries, produced by reputable manufacturers, are made in such a way that different cells can be used in the same housing. Thanks to this, one can put more or less energy in the same volume, more often or less frequently charge, with higher and lower currents, depending on the needs of the operator.

In the mentioned bus producer can install batteries with cells of different types. The bus holds from 2 to 6 batteries. This allows to take on board from 60 to $300 \mathrm{kWh}$, depending on the number of batteries and cell type. The energy can be from $60 \mathrm{kWh}$ (2 LTO batteries) to $300 \mathrm{kWh}$ (6 NMC batteries). This gives a range of 50 to $250 \mathrm{~km}$ on a single charge. Bus parameters for 6 batteries of different 


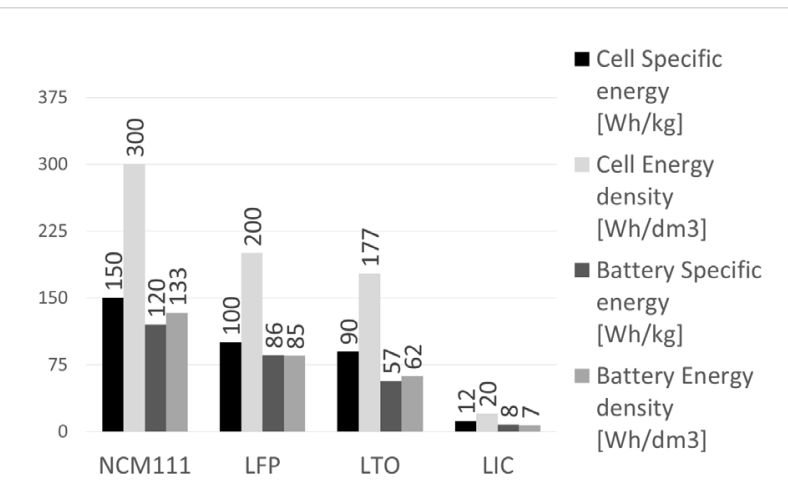

Figure 5. Energy density and specific energy of selected cells and batteries made of them

Table 4. Comparison of bus performance equipped with batteries of various types

\begin{tabular}{lllll}
\hline $\begin{array}{l}\text { Cell } \\
\text { type }\end{array}$ & $\begin{array}{l}\text { Max. } \\
\text { batt. } \\
\text { capacity }\end{array}$ & Range & $\begin{array}{l}\text { Min. } \\
\text { char. } \\
\text { time } \\
80 \% \\
\text { DoD }\end{array}$ & $\begin{array}{l}\text { Max. } \\
\text { char. } \\
\text { curr. }\end{array}$ \\
\hline & {$[\mathrm{kWh}]$} & {$[\mathrm{km}]$} & {$[\mathrm{min}]$} & {$[\mathrm{A}]$} \\
\hline NMC & 300 & 250 & 45 & 900 \\
LFP & 240 & 200 & 15 & 1500 \\
LTO & 120 & 90 & 5 & 1800 \\
LIC & 10 & 5 & 0,33 & 3000 \\
\hline
\end{tabular}

types are presented in the table 4 and figure 6 comparison of range.

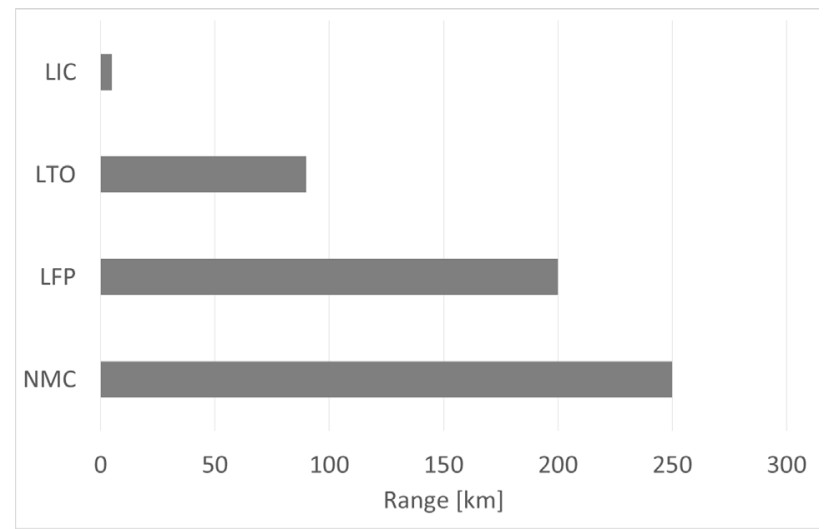

Figure 6. Comparison of bus ranges equipped with batteries made using different types of cells

How does it translate into mass? This is represented by the graph 7 and table 5. One can see that the batteries with LFP cells add the most mass to the vehicle, and do not give the largest range. This is why they are being replaced with NMC cells batteries, although they are safer and can work at lower temperatures. LTO and LIC cells, on the other
Table 5. Comparison of the parameters of buses equipped with batteries of various types

\begin{tabular}{llllll}
\hline $\begin{array}{l}\text { Cell } \\
\text { type }\end{array}$ & $\begin{array}{l}\text { Max. } \\
\text { batt. } \\
\text { capac- } \\
\text { ity }\end{array}$ & Range & $\begin{array}{l}\text { Max. } \\
\text { batt. } \\
\text { mass }\end{array}$ & $\begin{array}{l}\text { Max. } \\
\text { mass } \\
\text { of } \\
\text { elec- } \\
\text { tric } \\
\text { drive }\end{array}$ & $\begin{array}{l}\text { Mass } \\
\text { differ- } \\
\text { ence } \\
\text { of } \\
\text { drives }\end{array}$ \\
\hline & {$[\mathrm{kWh}]$} & {$[\mathrm{km}]$} & {$[\mathrm{t}]$} & {$[\mathrm{t}]$} & {$[\mathrm{t}]$} \\
\hline NMC & 300 & 250 & 2.5 & 3.1 & 2.0 \\
LFP & 240 & 200 & 2.8 & 3.4 & 2.3 \\
LTO & 120 & 90 & 2.1 & 2.7 & 1.6 \\
LIC & 10 & 5 & 1.9 & 2.5 & 1.4 \\
\hline
\end{tabular}

hand, give the smallest gains, but require frequent and fast charging.

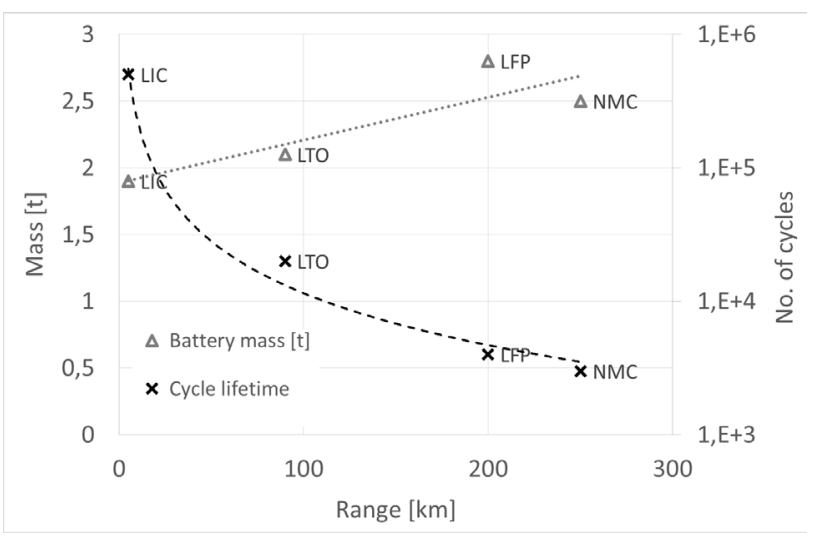

Figure 7. Mass and number of battery cycles as a function of the bus range for various cell types

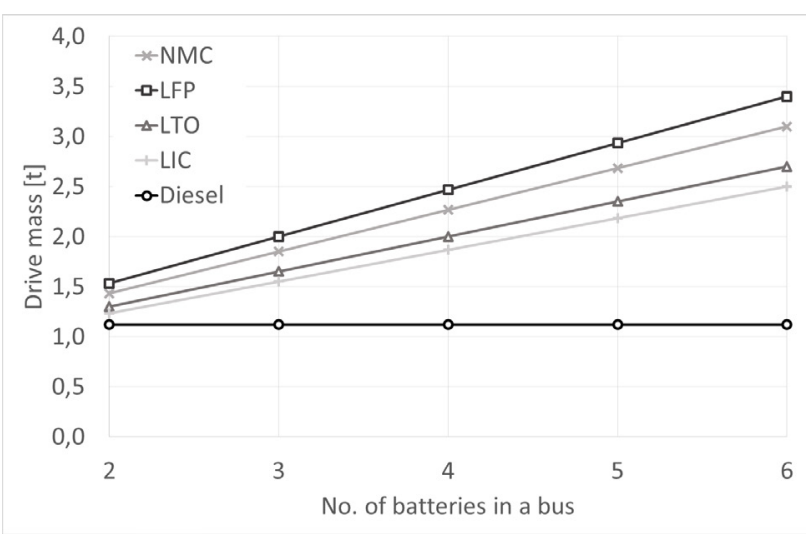

Figure 8. The mass of the drivetrain as a function of the number of batteries and the mass of the diesel engine drivetrain

The figure 8 shows the mass of the electric drive depending on the cell type of the number of batteries used in a bus. For comparison, the mass of the diesel dravietrain bus was added. It is clearly visible that in every variant an 
electric bus has higher mass than a bus with diesel drivetrain. Hence, fewer number of passengers.

The figure 9 shows the range of an electric bus as a function of the number of batteries for different types of cells. These values are several times smaller than the range of the vehicle driven by a diesel engine.

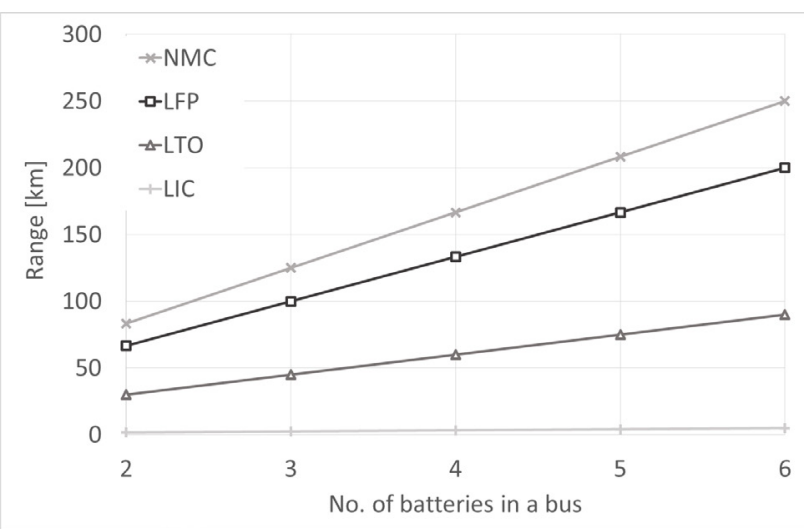

Figure 9. Electric bus range versus no. of installed batteries

The investor should choose which bus will be better for it, what type of cells should be used and the number of batteries installed on board. For long routes with little load, buses with NMC batteries will be better. And for shorter routes, with a large number of passengers better are ones with LTO cells. However, they will require frequent fast charging at the ends of the line.

\section{Charging strategies}

Depending on the type of cells used and the resulting range of the bus, it is necessary to adapt the charging strategy and to build the appropriate infrastructure.

In general, one can distinguish the following charging strategies:

- daily low current night charging,

- fast recharging at the end of the route and slow night equalizing charging,

- fast charging at the ends of the route,

- fast recharging at selected stops and fast charging at ends of the line.

The basic method is to charge the battery overnight. Large capacity batteries can be charged with small C-rate currents. This allows one to use low power chargers, but it requires a lot of time due to the high battery capacity. Thus it is made at night in the depots. This charging strategy is used for batteries with NMC and LFP cells.

In order to avoid the installation of many charging systems in bus depots and to increase the availability of buses, the second strategy is applied: night charging takes place once or twice a week to equalize the battery and restore the capacity, and is topped up with recharging at the ends of the route. Thanks to this, the battery performs more shallow cycles, which can increase its durability and allow one
Table 6. Charging stretegies and cells types used in the bus

\begin{tabular}{ll}
\hline Charging strategy & Cell type \\
\hline daily, low current full charging, @ night & NMC, LFP \\
recharging @ route end, equalizing & NMC, LFP \\
charge @ night & \\
fast charging @ route end & LTO \\
fast charging @ route end and recharg- & LTO, LIC \\
ing @ bus stops & \\
\hline
\end{tabular}

to extend the daily distance traveled by the bus. This is the strategy used for NMC, LFP as well as LTO.

Small capacity batteries can, however, do so many cycles that one can abandon slow night charging. The bus is only charged at the ends of the route, and charging in the depot is incidental, serving only battery maintenance. This charging strategy can be used for LTO cells.

The last charging strategy is necessary when using LIC cells. These cells have so small capacity that the vehicle must be recharged every few kilometers. These strategies can also be used for LTO cells to reduce the depth of discharge cycles and increase lifetime.

\section{Conclusions}

In public transport, the number of transported passengers is one of the most important coeficients as well as the distance to which they can be transported. The individual route lines differ in the terrain profile, the number and distance between the stops and the number of streetlights. All these parameters influence on power consumption per kilometer and passenger and the selection of batteries for the bus.

An electric bus of a fixed size has a larger mass and a smaller range than an internal combustion engine bus. As shown above, currently the mass of an electric bus is always greater than that of a comparable diesel one. This means that an electric bus can carry fewer people without increasing the total weight.

The problem may be solved by installing of a smaller number of lighter batteries. This will allow one to take a larger number of passengers. But the bus will be able to drive a smaller distance on one charge. The greater the number of passengers, the battery is smaller and the number of charging and discharging cycles is higher.

Therefore, it is necessary to associate the bus charging strategy with the number of passengers to be transported, required range and route profile. Large capacity and small C-rate current batteries (NMC, LFP) must be charged longer, but less frequently. This is done at night in depots. To increase the service life, these batteries can be recharged at selected points in the route to reduce the depth of discharge of the cycles. Small capacity batteries and high C-rate charging currents (LTO, LIC) must be charged more often, even every few kilometers. Charging must take place at selected points of the route. In the case of LIC cell, it must even take place every few stops.

At present, buses are equipped mainly with NMC and LTO batteries, moreover LFP. The first are used for vehi- 
cles that are to travel long distances on a single charge. The second onea are used where one need to carry more passengers. This is payed by a larger number of short loads. In both cases, the number of cell cycles, performed by battery, means that the battery life, calculated in years, is similar.

The trend for giving up batteries made of LFP cells is surging. These cells, despite better electrical performance and safety, are gradually replaced by batteries with NMC cells, because they have a significantly larger mass with less capacity.

In the discussion, the authors focused on technical parameters. The financial aspect was omitted. In practice, the dominant indicator is the cost of the bus, vehiclekilometer and accompanying infrastructure. In the case of lithium-ion cells, the price of cells is the smaller, the more energy they have.

All these problems cause that choosing a battery type for an electric bus is a difficult matter and one general and always true solution can not be given. Thus, the diversity of solutions offered even by one manufacturer.

\section{References}

[1] zeeus, ZeEUS eBus Report. An overview of electric buses in Europe, Tech. rep., ZeEUS project, UITP, the International Association of Public Transport (2016), [access: 2018-01-10 13:00CET, http://zeeus.eu/uploads/publications/documents/ zeeus-ebus-report-internet.pdf]
[2] zeeus2, ZeEUS eBus Report 2. An updated overview of electric buses in Europe, Tech. rep., ZeEUS project, UITP, the International Association of Public Transport (2018), [access: 2018-02-20 13:00CET, http://zeeus.eu/uploads/publications/documents/ zeeus-janvier2018-final.pdf]

[3] D. Linden, T.B. Reddy, Handbook of batteires, 3rd edn. (McGraw-Hill Professional, 2001), ISBN 007-135978-8

[4] K. Young, C. Wang, L.Y. Wang, K. Strunz, Electric Vehicle Battery Technologies (Springer, 2013), chap. 2, pp. 15-56

[5] D. Anseán, M. González, J.C. Viera, J.C. Álvarez, C. Blanco, V.M. García, Evaluation of LiFePO4 batteries for Electric Vehicle applications, in 2013 International Conference on New Concepts in Smart Cities: Fostering Public and Private Alliances (SmartMILE) (2013), pp. 1-8

[6] J. Mei, E.K.W. Cheng, Y.C. Fong, Lithium-titanate battery (LTO): A better choice for high current equipment, in 2016 International Symposium on Electrical Engineering (ISEE) (2016), pp. 1-4

[7] J. Ronsmans, B. Lalande, Combining energy with power: Lithium-Ion Capacitors, in 2016 International Symposium on Power Electronics, Electrical Drives, Automation and Motion (SPEEDAM) (2016), pp. 261264

[8] P. Lima, SK innovation to start producing NCM 811 battery cells soon, [online] (2017), [access: 201801-10 12:00CET, https://pushevs.com/2017/09/02/ sk-innovation-start-producing-ncm-811-battery-cells-soon/] 